до вивчення української лексики у 5-6 класах шкіл 3 російською мовою навчання: дис. на здобуття наук. ступеня канд. пед. наук: 13.00.02 / Дороз Вікторія Федорівна. - Бердянськ, 2005. - 270 с. 5. Костомаров В. Г. Методика преподавания русского языка как иностранного / В. Г. Костомаров, О. Д. Митрофанова. - Москва : Русский язик, 1990. - 269 с. 6. Ушакова Н. І. Концепція мовної підготовки іноземців у ВНЗ України / Н. І. Ушакова, В. В. Дубичинський, О. М. Тростинська // Викладання мов у вищих навчальних закладах освіти. Міжпредметні зв'язки : [зб. наук. праць]. - Харків : ХНУ ім. В. Н. Каразіна, 2011. Вип. 19. - С. 136-146. 7. Щукин А. Н. Методика преподавания русского языка как иностранного: [учебное пособие для вузов]/ Анатолий Николаевич Щукин. - Москва : Высшая школа, 2003. - 334 с.

\title{
ВЕРБАЛЬНІ ЧИННИКИ УСПІШНОГО ВЕБ-КУРСУ
}

Дубцова О. В. Вербальні чинники успішного веб-курсу.

Стаття присвячена розкриттю впливу вербальних чинників на сприйняття інформації у процесі навчання. У роботі обгрунтовано доцільність врахування вербальних чинників під час створення веб-курсу як елементів, що відіграють провідну роль у сприйнятті та опануванні навчального матеріалу. Надано загальні рекомендації, які слід враховувати у процесі підготовки веб-курсу, зокрема окреслено особливості створення веб-курсу 3 іноземної мови.

Ключові слова: веб-курс, вербальні засоби комунікації, інформаційно-комунікаційні технології, навчальний процес.

Дубцова О. В. Вербальные факторы успешного веб-курса.

Статья посвящена раскрытию влияния вербальных факторов на восприятие информации в процессе обучения. В работе обоснована целесообразность учета вербальных факторов при создании веб-курса в качестве элементов, играющих ведущую роль в восприятии и освоении учебного материала. Представлены общие рекомендации, которые следует учитывать в процессе подготовки веб-курса, в частности обозначены особенности создания веб-курса по иностранному языку.

Ключевые слова: веб-курс, вербальные средства коммуникации, информационнокоммуникационные технологии, учебный процесс.

Dubtsova O. V. Verbal factors of an effective web course.

The article studies the influence of verbal factors on the information perception while learning. The paper proves the expediency of considering verbal factors when creating a web course, as elements, playing a leading role in the perception and mastering of educational material. We have supplied general guidelines, which should be taken into account when preparing a web course as well as outlined some particular features of creating a web course in a foreign language.

Key words: educational process, information and communications technologies, verbal means of communication, web course.

Актуальність роботи визначаться необхідністю пошуку нових форм взаємодії викладача-студента в межах навчального процесу задля відповідності вимогам сучасної 
системи вищої освіти.

Метою статті є дослідження ролі вербальних чинників веб-курсу.

На сучасному етапі інформатизації освіти спостерігається прогрес у появі нових підходів до методів навчання задля вдосконалення викладання окремих дисциплін, зокрема іноземної мови. Сучасні інформаційно-комунікаційні технології навчання займають одне 3 провідних місць серед багатьох нових напрямів розвитку освіти, надаючи викладачу потужний набір інструментів, які мають ефективно використовуватися для досягнення цілей навчального процесу.

У викладанні іноземної мови персональний комп’ютер розглядається як засіб навчання, що дає змогу організувати керовану, самостійну роботу студентів. Через те, що в немовних ВНЗ на вивчення іноземної мови відводиться недостатньо часу, значну частину роботи студенти виконують самостійно. Новий матеріал, поданий викладачем в аудиторії, потребує повторення та закріплення. До того ж у студента можуть виникнути труднощі 3 опануванням певного обсягу навчального матеріалу. Розв’язати цю проблему допомагає вебкурс, який є дисциплінарним мультимедійним курсом. Основною метою веб-курсу $є$ «підвищення ефективності навчальної діяльності студентів за рахунок використання дидактичних засобів інформаційно-комунікаційних технологій та покращення якості підготовки фахівців за допомогою організації системи управління навчанням і самоосвітою студентів» [6, с. 205].

Для створення успішного веб-курсу викладачу необхідно чітко усвідомлювати його цілі. Серед основних вимог слід виокремити такі:

- орієнтація на конкретну освітню програму;

- відповідність віковим та психофізіологічним особливостям студента;

- відповідність рівню предметної підготовки студента;

- відповідність навчальному плану за кількістю годин, що відводяться на опанування певної програми [4, с. 14].

У найбільш повному варіанті веб-курс має містити такі елементи:

- анотацію навчального курсу, навчальний план та програму дисципліни, що сприятиме прозорості навчального процесу, тобто студент матиме змогу заздалегідь ознайомитись з навчальним обсягом і очікуваним кінцевим результатом навчання;

- навчальну інформацію у формі лекцій, наочно-ілюстрованого матеріалу (презентацій, аудіо-, відео-, фотоматеріалів, малюнків, схем, таблиць, Flash-анімацій), медіаресурсів (віртуальні лабораторії), довідкових матеріалів (словники, тематичні довідники, онлайн-енциклопедії) тощо;

- методичні рекомендації щодо виконання практичної, самостійної роботи;

- покликання на інформаційні ресурси (навчальну та довідкову літературу, освітні сайти, навчальні та науково-популярні фільми);

- контрольно-вимірювальні матеріали (тестові завдання, кейс-завдання тощо) [6, с. 206].

Під час викладу навчального матеріалу слід спиратися на такі дидактичні принципи:

- науковість - орієнтація на формування у студентів наукового світосприйняття, відповідність навчальних матеріалів сучасному стану науки;

- доступність - відповідність ступеня теоретичної складності та глибини опанування навчального матеріалу віковим та індивідуальним особливостям студентів;

- проблемність - стимулювання розумової активності студентів у процесі навчання 
шляхом створення навчальних проблемних ситуацій;

- наочність - створення можливостей для візуального сприйняття досліджуваних об’єктів;

- свідомість навчання - забезпечення умов для самостійних дій студентів з вилучення навчальної інформації при чіткому розумінні кінцевих цілей і завдань навчальної діяльності;

- систематичність і послідовність навчання - забезпечення послідовного засвоєння студентами певної системи знань у межах навчальної дисципліни;

- міцність засвоєння знань - створення умов для глибокого осмислення навчального матеріалу та його розосередженого запам’ятовування;

- єдність навчальних, розвивальних і виховних технологій [3, с. 89].

У цій роботі ми зосередимось переважно на вербальних чинниках успішності вебкурсу. Для цього необхідно чітко усвідомлювати, що саме розуміють під вербалікою.

«Вербальна комунікація є словесною взаємодією сторін та реалізується за допомогою знакових систем, головною з яких є мова. Мова як знакова система $є$ оптимальним засобом відображення людського мислення та засобом спілкування, який реалізується в мовленні» [5, с. 92-93]. Домінуючою функцією мовлення є комунікативна функція.

Вербальні компоненти відіграють провідну роль у міжособистісному спілкуванні. Під вербальними компонентами розуміють «засоби мовного коду, тобто слова, словосполучення, речення (повідомлення), за допомогою яких передається інформація» [1, с. 62]. Вербальні компоненти справедливо вважають «найважливішими складовими комунікативного акту, оскільки саме вони в нормальному (неспеціалізованому) міжособистісному спілкуванні $€$ основними носіями значень (смислів) повідомлень» [1, с. 64].

«До вербальних засобів комунікації належать говоріння (письмове та усне мовлення), слухання та читання. Усне та письмове мовлення беруть участь у створенні тексту (процес передачі інформації), а слухання та читання - у сприйнятті тексту, закладеної в ньому інформації» [2, с. 31].

Отже, для того щоб забезпечити якість навчальної інформації, слід особливу увагу приділяти використанню мовних засобів.

Працюючи з текстом навчального курсу, необхідно виконати його структурування із визначенням точного переліку усіх необхідних тем, які мають бути викладені в цьому курсі, розподілом на розділи (модулі), параграфи тощо. Для того щоб студенти могли самостійно працювати 3 матеріалом курсу, має бути наданий детальний опис раціональних прийомів усіх видів діяльності, критеріїв правильності розв’язання завдань, а також рекомендації щодо ефективного використання всіх матеріалів курсу [7].

Під час формування навчального тексту слід враховувати такі вимоги та рекомендації:

1. Навчальні матеріали мають бути ретельно вивірені на наявність фактичних помилок у науково-предметній галузі та мають забезпечувати науковість під час викладу навчального матеріалу.

2. Текст має забезпечувати коректність викладу навчального матеріалу, що передбачає відсутність граматичних і синтаксичних помилок у навчальному матеріалі, грамотну мову в звукових фрагментах.

3. Текст має забезпечувати доступність викладу навчального матеріалу з урахуванням вікових особливостей групи студентів, на яких пріоритетно орієнтований електронний навчальний курс.

4. У змісті навчального курсу бажано використовувати приклади, що сприяє 
конкретизації теоретичного матеріалу. Особливо виразними $є$ приклади, що апелюють до особистого досвіду студента, його спостережень, оскільки вони не тільки конкретизують теорію, але й стимулюють мотивацію студента до вивчення предмета.

5. Текст навчального курсу має містити чіткі та зрозумілі вказівки щодо послідовності виконання дій: прочитати, відповісти на запитання, виконати завдання або вправи тощо [3, с. 90].

Особливу увагу слід також звернути на стилістику навчального тексту.

Бажано використовувати стилістику, відповідну жанру навчальної та науковопопулярної літератури, уникаючи складних граматичних конструкцій. Нові поняття і терміни слід роз’яснювати при першому згадуванні в тексті [3, с. 91].

Не слід також забувати про заголовки та підзаголовки, оскільки вони відіграють важливу роль у сприйнятті матеріалу. Вони не мають бути занадто загальними, важливо, щоб заголовок був лаконічним, точно відображав зміст матеріалу, тим самим мотивуючи студента до роботи, стимулюючи його інтерес до опанування навчального матеріалу [3, с. 90].

Під час складання тестових завдань для контролю і самоконтролю знань, завдяки яким викладач має змогу отримати цілісну картину досягнень студента, необхідно дотримуватись таких правил:

- формулювання запитання має бути однозначним і не допускати різних трактувань;

- якщо в завданні потрібно структурувати або систематизувати матеріал, то він має бути підібраний так, щоб була лише одна підстава для систематизації або структурування;

- запитання мають бути зорієнтовані на значущі фрагменти змісту, а не на дрібниці;

- формулювання запитання або завдання не має містити підказок;

- запитання та завдання краще розташовувати в порядку поступового зростання складності;

- завдання для самоконтролю i закріплення не мають дублюватися в контрольних запитаннях;

- бажано, щоб після виконання тренувального завдання була забезпечена перевірка правильності його виконання з необхідним коментарем [3, с. 91-92].

Під час створення веб-курсу з іноземної мови слід чітко усвідомлювати рівень володіння мовою студентами. Відтак, добирати вправи на розвиток навичок читання, аудіювання, письмового та усного мовлення, які б були посильні для студентів та сприяли ефективному закріпленню вже набутих знань, а також засвоєнню нових.

Підсумовуючи все зазначене вище, зауважимо, що використання інформаційнокомунікаційних технологій значно розширяє та урізноманітнює програму вивчення іноземної мови у виші. При вдалому виборі матеріалу та його цілеспрямованому плануванні, ці технології сприяють зацікавленості студентів у вивченні іноземної мови, надаючи їм доступ до різноманітних автентичних матеріалів, роблять їх більш організованими та дисциплінованими, незалежними, розширюють їх мотивацію, надають можливість працювати над мовою в зручний для них час, сприяючи таким чином результативності навчального процесу. Веб-курс $є$ лише одним із засобів навчання студентів, у якому важливу роль відіграють вербальні компоненти, які є «обличчям» курсу. Тож вони однаковою мірою можуть як привернути увагу студента, так і відвернути їі. Ось чому особливу увагу при складанні веб-курсу слід звернути на мову, якою подається інформація, адже вона повинна бути доступною, прозорою та зрозумілою, для того щоб не налякати студента, який і так 
відчуває страх перед невідомим, а зацікавити його, насамперед для того, щоб утримати його увагу якнайдовше.

\section{Література}

1. Бацевич Ф. С. Основи комунікативної лінгвістики : [підручник] / Ф. С. Бацевич. [2-е вид., доп.]. - Київ : ВЦ «Академія», 2009. - 376 с. 2. Володина Л. В. Деловое общение и основы теории коммуникации : [учеб.-метод. пособие] / Л. В. Володина, О. К. Карпухина. Санкт-Петербург : СПбГУТ, 2002. - 56 с. 3. Давыдова И. П. Педагогам о дистанционном обучении : [методическое пособие] / И. П. Давыдова, М. Б. Лебедева, И. Б. Мылова и др. [под ред. Т. В. Лазыкиной]. - Санкт Петербург : РЦОКОиИТ, 2009. - 98 с. 4. Мылова И. Б. Инновации в образовании: дистанционное обучение: [методическое пособие] / И. Б. Мылова, $\quad$ В. Л. Матвеев, $\quad$ А. И. Мочкина, $\quad$ Т. М. Прокофьева. - Санкт-Петербург : СПбАППО, 2009. - 119 с. 5. Николаева Ж. В. Основы теории коммуникации : [учеб.-метод. пособие для студентов спец. 350400 «Связи с общественностью»] / Ж. В. Николаева. - УланУдэ : ВСГТУ, 2004. - 274 с. 6. Ребрина Ф. Г. Этапы разработки электронного учебного курса на платформе LMS Moodle / Ф. Г. Ребрина, И. А. Леонтьева // Вестник Челябинского государственного педагогического университета. - 2014. - № 2. - С. 204-213. 7. Саитова А. С. Рекомендации по созданию курса, предназначенного для размещения на сайте дистанционного обучения [Электронный ресурс] / А. С. Саитова. - ТГСПА им. Д. И. Менделеева. - Режим доступу : http://distance.tgspa.ru/file.php/1/rekomendacii/ Rekomendaci_po_sozdaniy_kursa.pdf.

УДК 371.333+371.13+37.018.46

Людмила Калачова

\section{ПЕДАГОГІЧНА ТЕХНОЛОГІЯ ПІДГОТОВКИ ВИКЛАДАЧІВ ІНСТИТУТІВ ПІСЛЯДИПЛОМНОЇ ПЕДАГОГІЧНОЇ ОСВІТИ ДО ЗАСТОСУВАННЯ АУДІОВІЗУАЛЬНИХ ЗАСОБІВ НАВЧАННЯ}

Калачова Л. В. Педагогічна технологія підготовки викладачів інститутів післядипломної педагогічної освіти до застосування аудіовізуальних засобів навчання.

У статті описано компоненти педагогічної технології підготовки викладачів інститутів післядипломної педагогічної освіти до застосування аудіовізуальних засобів навчання: організаційно-діагностичний, змістово-процесуальний та аналітико-рефлексивний.

Ключові слова: аудіовізуальні засоби навчання, післядипломна педагогічна освіта, педагогічна технологія, компоненти педагогічної технології.

Калачёва Л. В. Педагогическая технология подготовки преподавателей институтов последипломного педагогического образования $\mathrm{K}$ применению аудиовизуальных средств обучения.

В статье описаны компоненты педагогической технологии подготовки преподавателей институтов последипломного педагогического образования к применению аудиовизуальных средств обучения: организационно-диагностический, содержательнопроцессуальный и аналитико-рефлексивный.

Ключевые слова: аудиовизуальные средства обучения, последипломное педагогическое образование, педагогическая технология, компоненты педагогической технологии.

Kalachova L. V. Technology of postgraduate education teachers' training to the use of 